A fusion there is an increase in oxygen consumption and energy expenditure that has been referred to as thermogenesis. To examine the contribution of the beta and alpha adrenergic nervous system to this thermogenic response, 12 healthy volunteers participated in three studies: (a) euglycemic insulin (plasma insulin $\sim 100 \mu \mathrm{U} / \mathrm{ml}$ ) clamp study $(n=12) ;(b)$ insulin clamp study after beta adrenergic blockade with intravenous propranolol for 1 $\mathrm{h}(n=12) ;(c)$ insulin clamp study after alpha adrenergic blockade with phentolamine for $1 \mathrm{~h}(n=5)$.

During the control insulin clamp study total glucose uptake, glucose oxidation and nonoxidative glucose uptake averaged $7.85 \pm 0.47,2.62 \pm 0.22$, and $5.23 \pm 0.51 \mathrm{mg} /$ $\mathrm{kg} \cdot \min$. After propranolol infusion, insulin-mediated glucose uptake was significantly reduced, 6.89 $\pm 0.41(P$ $<0.02)$. This decrease was primarily the result of a decrease in glucose oxidation $(1.97 \pm 0.19 \mathrm{mg} / \mathrm{kg} \cdot \mathrm{min}, P$ $<0.01$ ) without any change in nonoxidative glucose metabolism. Phentolamine administration had no effect on total glucose uptake, glucose oxidation, or nonoxidative glucose disposal. The increments in energy expenditure $(0.10 \pm 0.01$ vs. $0.03 \pm 0.01 \mathrm{kcal} / \mathrm{min})$ and glucose $/$ insulininduced thermogenesis $(4.9 \pm 0.5$ vs. $1.5 \pm 0.5 \%)$ were reduced by $70 \%$ during the propranolol/insulin clamp study. The increments in energy expenditure $(0.12 \pm 0.03 \mathrm{kcal} /$ min) and thermogenesis $(5.0 \pm 1.5 \%)$ were not affected by phentolamine. These results indicate that activation of

Address reprint requests to Dr. DeFronzo at Yale University School of Medicine. 1983.

Received for publication 9 May 1983 and in revised form 3 October

J. Clin. Invest.

(c) The American Society for Clinical Investigation, Inc. 0021-9738/84/03/0633/07 \$1.00

Volume 73, March 1984, 633-639

\section{Effect of Beta and Alpha Adrenergic Blockade on Glucose-induced Thermogenesis in Man}

\author{
R. A. Defronzo, D. Thorin, J. P. Felber, D. C. Simonson, \\ D. Thiebaud, E. Jequier, and A. Golay \\ Department of Medicine, Yale University School of Medicine, \\ New Haven, Connecticut 06510; Division of Endocrinology and \\ Clinical Biochemistry, Centre Hospitalier Universitaire Vaudois, \\ Division of Clinical Physiology, University of Lausanne, 1011 \\ Lausanne, Switzerland
}

the beta adrenergic receptor plays an important role in the insulin/glucose-mediated increase in energy expenditure and thermogenesis. In contrast, the alpha adrenergic receptor does not appear to participate in this response.

\section{Introduction}

After the ingestion or intravenous administration of nutrients, there is an increase in oxygen consumption and energy expenditure (1-13) that has been referred to as "nutrient" or "dietary" induced thermogenesis. This thermogenic response to food occurs after protein, fat, and carbohydrate feeding (1-13) and has been described in man (1-13) as well as in animals (14-16). However, the physiologic mechanism(s) responsible for this thermogenic response have not been clarified.

A variety of factors could potentially contribute to the increase in energy expenditure that accompanies insulin/glucose administration: (a) the cost of glucose conversion to glycogen $(13,17),(b)$ recycling of glucose to three carbon compounds and back to glucose or glycogen (17-20), (c) the cost of glucose conversion to lipid (17), (d) stimulation of the Na-K ATPase pump located in the cell membrane (21), (e) activation of the sympathetic nervous system (1, 22-29), and/or $(f)$ other, as of yet unidentified, factors.

Previous studies have shown that both norepinephrine (30) and epinephrine (31) will cause an increase in oxygen consumption and energy expenditure. When glucose is ingested or infused intravenously, the sympathetic nervous system is activated (1, 22-29). Therefore, it is possible that a significant portion of the thermogenic response results from stimulation of sympathetic nervous system activity. In the present study we have used the euglycemic insulin clamp and indirect calorimetry techniques, in combination with beta (propranolol) and alpha (phentolamine) adrenergic blockade, to examine the contribution of increased sympathetic nervous system activity to the increase in energy expenditure that occurs after insulin/glucose infusion.

\section{Methods}

Subjects. 12 healthy volunteers, ranging in age from 21 to 39 years (mean \pm SEM $=25 \pm 1 \mathrm{yr}$ ) were studied. There were eight males and four 
females. Their ideal body weight (based on medium-frame individuals from the Metropolitan Life Insurance Tables, 1959) ranged from 81 to $115 \%$ (mean $=102 \pm 3 \%$ ). Their mean height and weight were $175 \pm 2$ $\mathrm{cm}$ and $70.5 \pm 3.2 \mathrm{~kg}$, respectively. None of the subjects had any family history of diabetes mellitus and none was taking any medication. All participants were consuming a weight-maintaining diet that contained at least $250-300 \mathrm{~g}$ of carbohydrate per day for $3 \mathrm{~d}$ before each study. Before their participation, the nature, purpose, and risks of the study were explained to all subjects and their voluntary consent was obtained. The experimental protocol was approved by the human investigation committees of the Department of Medicine of the University of Lausanne, Switzerland, and the Yale University School of Medicine, New Haven, CT.

Experimental protocol. All studies were performed in the recumbent position at 8:00 a.m. after a 10-12-h overnight fast. A Teflon catheter was inserted into an antecubital vein for the infusion of all test substances. For blood sampling, a second catheter was inserted retrogradely into a wrist vein and kept patent with an infusion of isotonic saline. The hand was then inserted into a heated box $\left(70^{\circ} \mathrm{C}\right)$ to achieve arterialization of the venous blood (32). $45 \mathrm{~min}$ before beginning the insulin clamp studies, or before beginning the propranolol/phentolamine infusion, continuous respiratory exchange measurements were begun and continued throughout the duration of the experimental protocol.

Subjects participated in the following four protocols. Study one: After a 45-min period of continuous respiratory-exchange measurements, all 12 subjects received a 2-h euglycemic insulin clamp study as described below. Indirect calorimetry measurements were continued throughout. Study two: In the same 12 subjects, after $45 \mathrm{~min}$ of respiratory-exchange measurements, propranolol was infused intravenously for a period of 3 h. Propranolol was administered intravenously as a prime $(200 \mu \mathrm{g} / \mathrm{kg}$ over $20 \mathrm{~min})$-continuous $(80 \mu \mathrm{g} / \mathrm{min})$ infusion. $1 \mathrm{~h}$ after beginning the propranolol infusion, a 2-h insulin clamp study was performed. Study three: In six subjects after $\mathbf{4 5}$ min of continuous respiratory-exchange measurements, propranolol was infused for $3 \mathrm{~h}$, as in study two. These six subjects served as time controls for the effect of propranolol. Study four: In nine subjects who participated in study one, after $45 \mathrm{~min}$ of respiratory-exchange measurements, phentolamine was administered as a prime $(70 \mu \mathrm{g} / \mathrm{kg}$ over $5 \mathrm{~min})$-continuous $(7 \mu \mathrm{g} / \mathrm{kg} \cdot \mathrm{min})$ infusion. $1 \mathrm{~h}$ after starting the phentolamine infusion, a $2-\mathrm{h}$ insulin clamp study was performed. In four of the nine subjects the study had to be discontinued during the initial $60-\mathrm{min}$ period of phentolamine alone or during the first $30 \mathrm{~min}$ of the insulin clamp/phentolamine period because of severe nasal stuffiness, which resulted in difficulty in breathing within the hood. All four of these subjects had a significant increase in respiratory rate and asked to have the study stopped. The other five subjects experienced little or no nasal stuffiness and had no difficulty breathing. There was no increase in their respiratory rate. Other than nasal stuffiness and breathing difficulty, none of the nine subjects had any other symptoms or complaints. Consequently, in only five subjects could the effect of phentolamine on insulin-mediated glucose metabolism be evaluated.

Euglycemic insulin clamp. After base-line respiratory-exchange measurements, a 2-h euglycemic insulin clamp study was performed as previously described (33). Briefly, a prime-continuous $(1 \mathrm{mU} / \mathrm{kg} \cdot \mathrm{min})$ infusion of crystalline porcine insulin was administered to acutely raise and maintain the plasma insulin concentration by $\sim 100 \mu \mathrm{U} / \mathrm{ml}$. The plasma glucose concentration was held constant at basal preinfusion levels by determination of the plasma glucose concentration every 5 min and periodically adjusting a variable $20 \%$ glucose solution based on a negative-feedback principle (33). In subjects who participated in repeated studies, the subsequent studies were performed 1-3 wk after the initial one. Each insulin clamp study lasted for $120 \mathrm{~min}$.
Respiratory exchange measurements. During the 45-min control period and throughout the 2-h insulin clamp studies, substrate utilization rates were determined by computerized open-circuit indirect calorimetry using a ventilated hood as previously described (12). The nonprotein respiratory quotient (NPRQ) ${ }^{1}$ was calculated from calorimetric values and urinary nitrogen (34). Estimation of carbohydrate (CHO) oxidation rate was obtained by using the table of Lusk (35) for NPRQ, which is based on 0.707 respiratory quotient for $100 \%$ fat oxidation and 1.00 for $100 \% \mathrm{CHO}$ oxidation. The quantity of urinary nitrogen excreted during the study period was used to obtain an index of the amount of protein oxidized, assuming that protein oxidation was relatively constant. It should be noted, however, that this assumption does not substantially affect the calculation of $\mathrm{CHO}$ oxidation (36). Lipogenesis from $\mathrm{CHO}$ does not invalidate calculation of $\mathrm{CHO}$ and lipid oxidation (37). The coefficients of variation of NPRQ and CHO oxidation rates were measured over five consecutive days and were 1.0 and $5.0 \%$, respectively.

\section{Analytical procedures}

Plasma glucose concentration was determined in duplicate by the glucoseoxidase method on a Beckman glucose analyzer II (Beckman Instruments, Inc., Fullerton, CA). Plasma immunoreactive insulin was determined by radioimmunoassay with talc to separate bound from free insulin (38). Urinary nitrogen was measured by the method of Kjedhal (39). Plasma catecholamines were measured by radioenzymatic assay as previously described (40) during the control insulin clamp and the propranolol/insulin clamp studies.

\section{Data analysis}

During the $120-\mathrm{min}$ insulin clamp study the glucose infusion rate was calculated at 20-min intervals. For data presentation, the mean of the three 20 -min values from 60 to $120 \mathrm{~min}$ is given. Hepatic glucose production was not determined in the present studies. However, it has been previously shown that in normal subjects infusion of insulin at a rate of $\geq 1 \mathrm{mU} / \mathrm{kg} \cdot \mathrm{min}$ (plasma insulin levels of $\sim 100 \mu \mathrm{U} / \mathrm{ml}$ ) suppresses hepatic glucose production by $>90-95 \%$ (41). Suppression of hepatic glucose production by insulin is not affected by concomitant propranolol infusion (42). Therefore, under the steady state conditions of euglycemia used in the present protocol, glucose uptake must be approximately equal to the rate of exogenous glucose infusion.

The glucose oxidation rate was calculated from calorimetric measurements for 5-min intervals during the basal state, after propranolol or phentolamine infusion, and throughout the 120 -min insulin clamp period. Nonoxidative glucose uptake (called "glucose storage" in our previous publications) was calculated by subtracting the rate of glucose oxidation during a given time period from the total rate of glucose uptake during the same time period. Presented values for glucose oxidation, total body glucose uptake, and nonoxidative glucose disposal represent the mean for the 60-120-min time period of the insulin clamp. To calculate steady state plasma glucose and insulin concentrations during the insulin clamp, the mean of values (every $5 \mathrm{~min}$ for glucose and every $10 \mathrm{~min}$ for insulin) from 60 to $120 \mathrm{~min}$ were used. The mean values during the 60-120-min time period were chosen to allow insulin to more fully exert its biologic effect. The values for glucose metabolism during propranolol or phentolamine infusion before beginning the insulin clamp represent the entire $60-\mathrm{min}$ period. The equations for the calculation of energy expenditure and substrate oxidation rates have been

1. Abbreviations used in this paper: $\mathrm{CHO}$, carbohydrate; NPRQ, nonprotein respiratory quotient. 
presented in detail in a previous publication (43). Insulin/glucose-induced thermogenesis was calculated from the difference between the energy expenditure during the $60-120-\mathrm{min}$ period of the euglycemic insulin clamp and the basal energy expenditure. The increment in energy expenditure (kilocalories per minute) was then divided by the energy infusion rate (kilocalories per minute). The rate of energy infusion was calculated from the product of the glucose infusion rate (grams per minute) and $3.75 \mathrm{kcal} / \mathrm{g}$ of glucose infused. This value is multiplied by 100 to express glucose-induced thermogenesis as a percentage of the rate of the energy infused.

All data are presented as the mean \pm SEM. Statistical comparisons were performed by unpaired or paired $t$ test analysis where appropriate. Coefficients of variation were determined by standard formulae.

\section{Results}

Plasma glucose and insulin (Table I). The mean fasting plasma glucose concentration $(88 \pm 2 \mathrm{mg} / \mathrm{dl})$ was similar in all three study protocols. During the $60-\mathrm{min}$ infusion of propranolol or phentolamine alone, the plasma glucose concentration did not change significantly from the fasting value. During the last 60 min of the control insulin clamp, the propranolol/insulin clamp, and the phentolamine/insulin clamp studies the steady state plasma glucose values were $86 \pm 2,86 \pm 2$, and $85 \pm 3 \mathrm{mg} / \mathrm{dl}$ with coefficients of variation of $2.5 \pm 0.3,2.6 \pm 0.5$, and $2.6 \pm 0.2 \%$, respectively. The fasting plasma insulin concentration was similar in all four groups and averaged $9 \pm 2 \mu \mathrm{U} / \mathrm{ml}$. After $1 \mathrm{~h}$ of propranolol infusion (study two), the plasma insulin concentration remained unchanged, $9 \pm 2 \mu \mathrm{U} / \mathrm{ml}$. Phentolamine infusion had no effect on the fasting insulin ( $10 \pm 2 \mu \mathrm{U} / \mathrm{ml}$ ) level (study four). During the $60-120-\mathrm{min}$ period of the control (study one), propranolol (study two) and phentolamine (study four) insulin clamp studies, the mean steady state plasma insulin concentrations were $93 \pm 8,92 \pm 8$, and $99 \pm 16 \mu \mathrm{U} / \mathrm{ml}$ with coefficients of variation of $10.1 \pm 0.9,8.9 \pm 1.0$, and $10.2 \pm 0.9 \%$, respectively. In study three, after $3 \mathrm{~h}$ of propranolol infusion the plasma insulin concentration decreased slightly from $8 \pm 1$ to $7 \pm 1$ $\mu \mathrm{U} / \mathrm{ml}$.

Glucose metabolism and energy expenditure (Tables I and II). During the control insulin clamp study, the total amount of glucose taken up by the entire body averaged $7.85 \pm 0.47 \mathrm{mg} /$ $\mathrm{kg} \cdot \min$ (Table I). During the propranolol/insulin clamp study, total glucose uptake decreased in 9 of 12 subjects to $6.89 \pm 0.41$ $\mathrm{mg} / \mathrm{kg} \cdot \min (P<0.02)$. Basal glucose oxidation was similar in both study protocols and averaged $1.07 \pm 0.12 \mathrm{mg} / \mathrm{kg} \cdot \mathrm{min}$. During the last hour of the euglycemic insulin clamp, glucose oxidation was significantly decreased in the propranolol compared with the control study $(1.97 \pm 0.19$ vs. $2.62 \pm 0.22 \mathrm{mg} / \mathrm{kg} \cdot \mathrm{min}$, $P<0.01)$. Nonoxidative glucose metabolism was not significantly altered by propranolol (Table I). When propranolol alone was infused for $3 \mathrm{~h}$ (study three), basal glucose oxidation did not change significantly $(1.66 \pm 0.13$ vs. $1.46 \pm 0.16 \mathrm{mg} / \mathrm{kg} \cdot \mathrm{min})$.

Basal energy expenditure was similar in the control insulin clamp $(1.11 \pm 0.06 \mathrm{kcal} / \mathrm{min})$ and propranolol/insulin clamp $(1.10 \pm 0.07 \mathrm{kcal} / \mathrm{min})$ studies (Table II). During the 60-120min period of hyperinsulinemia, the increase in energy expenditure was reduced by $70 \%(0.03 \pm 0.01$ vs. $0.10 \pm 0.01 \mathrm{kcal} / \mathrm{min}$, $P<0.001$ ) in the propranolol-infused group (Table II). Glucose/ insulin-induced thermogenesis was similarly reduced $(1.52 \pm 0.49$ vs. $4.90 \pm 0.51 \%, P<0.001)$. When propranolol was infused alone for $3 \mathrm{~h}$ in six subjects, basal energy expenditure $(1.36 \pm 0.04$ vs. $1.35 \pm 0.04 \mathrm{kcal} / \mathrm{min}$ ) did not change. Likewise, in the 12 subjects who received propranolol for $1 \mathrm{~h}$ before starting the insulin clamp, no change in basal energy expenditure was observed $(1.10 \pm 0.07$ vs. $1.09 \pm 0.07 \mathrm{kcal} / \mathrm{min})$. Phentolamine had no effect on total glucose uptake, glucose oxidation, or nonoxidative glucose disposal (Table I). When phentolamine was infused alone for $1 \mathrm{~h}$ before starting the insulin clamp, there was a small but statistically insignificant increase in basal energy expenditure $(0.99 \pm 0.06$ to $1.05 \pm 0.08, P=0.07)$. During the last hour of the phentolamine/insulin clamp, energy expenditure

Table I. Steady State Plasma Glucose and Insulin Concentrations, Total Body Glucose Uptake, Glucose Oxidation, and Nonoxidative Glucose Disposal during Euglycemic Insulin Clamp Studies Performed with and without Propranolol and Phentolamine

\begin{tabular}{|c|c|c|c|c|c|c|c|}
\hline & \multirow[b]{2}{*}{$n$} & \multirow[b]{2}{*}{$\begin{array}{l}\text { Steady state } \\
\text { plasma glucose }\end{array}$} & \multirow[b]{2}{*}{$\begin{array}{l}\text { Steady state } \\
\text { plasma insulin }\end{array}$} & \multirow[b]{2}{*}{$\begin{array}{l}\text { Total glucose } \\
\text { uptake }\end{array}$} & \multicolumn{2}{|c|}{ Glucose oxidation } & \multirow{2}{*}{$\begin{array}{l}\text { Nonoxidative } \\
\text { glucose } \\
\text { disposal* }\end{array}$} \\
\hline & & & & & Basal & Total & \\
\hline & & $m g / d l$ & $\mu U / m l$ & $m g / k g \cdot \min$ & $\mathrm{mg} / \mathrm{kg} \cdot \min$ & $\mathrm{mg} / \mathrm{kg} \cdot \mathrm{min}$ & $\mathrm{mg} / \mathrm{kg} \cdot \min$ \\
\hline $\begin{array}{l}\text { Insulin clamp } \\
\text { Insulin clamp }\end{array}$ & 12 & $86 \pm 2$ & $93 \pm 8$ & $7.85 \pm 0.47$ & $1.11 \pm 0.21$ & $2.62 \pm 0.22$ & $5.23 \pm 0.51$ \\
\hline+ propranolol & 12 & $87 \pm 2$ & $92 \pm 8$ & $6.89 \pm 0.41 \ddagger$ & $1.02 \pm 0.13$ & $1.97 \pm 0.19 \S$ & $4.92 \pm 0.46$ \\
\hline $\begin{array}{l}\text { Insulin clamp } \\
\text { Insulin clamp }\end{array}$ & 5 & $82 \pm 2$ & $100 \pm 17$ & $8.78 \pm 0.76$ & $1.20 \pm 0.33$ & $2.35 \pm 0.32$ & $6.43 \pm 0.61$ \\
\hline+ phentolamine & 5 & $86 \pm 2$ & $99 \pm 16$ & $8.08 \pm 1.23$ & $0.94 \pm 0.20$ & $2.16 \pm 0.28$ & $5.92 \pm 1.05$ \\
\hline
\end{tabular}

All values represent the mean \pm SEM for the $60-120$ min time period. $n$ refers to the number of subjects in each group. * Calculated as the difference between total body glucose uptake and total glucose oxidation. $\ddagger P<0.02$ compared with the control insulin clamp study. $\S P<0.01$ compared with the control insulin clamp study. 
Table II. Basal and Total Energy Expenditure and Glucose-induced Thermogensis during Euglycemic Insulin Clamp Studies Performed with and without Propranolol and Phentolamine

\begin{tabular}{lllll}
\hline & $\begin{array}{l}\text { Basal energy } \\
\text { expenditure }\end{array}$ & $\begin{array}{l}\text { Total energy } \\
\text { expenditure }\end{array}$ & $\begin{array}{l}\text { Increment in } \\
\text { energy expenditure }\end{array}$ & $\begin{array}{l}\text { Glucose-induced } \\
\text { thermogenesis* }\end{array}$ \\
\hline & kcal/min & kcal/min & $k$ cal/min & $\%$ \\
Insulin clamp & $1.11 \pm 0.06$ & $1.21 \pm 0.06$ & $0.10 \pm 0.01$ & $4.90 \pm 0.51$ \\
Insulin clamp + propranolol & $1.10 \pm 0.07$ & $1.13 \pm 0.07 \ddagger$ & $0.03 \pm 0.01 \ddagger$ & $1.52 \pm 0.49 \ddagger$ \\
Insulin clamp & $0.99 \pm 0.07$ & $1.11 \pm 0.09$ & $0.12 \pm 0.03$ & $5.75 \pm 0.52$ \\
Insulin clamp + phentolamine & $0.99 \pm 0.06$ & $1.17 \pm 0.09$ & $0.12 \pm 0.03$ & $4.98 \pm 1.54$ \\
\hline
\end{tabular}

All values represent the mean \pm SEM during the $60-120 \mathrm{~min}$ time period. $*$ Calculated from the product of the glucose infusion rate $(\mathrm{g} / \mathrm{min})$ $\times 3.75 \mathrm{kcal} / \mathrm{g}$ of glucose infused. This value is multiplied by 100 to express glucose induced thermogenesis as a percentage of the rate of energy infused. $¥ P<0.001$.

rose to $1.17 \pm 0.09, P<0.02$ vs. both basal and phentolaminealone periods (Table II). This increase may have occurred secondary to an unopposed beta adrenergic stimulatory effect that resulted from the alpha adrenergic blockade. Glucose/insulininduced thermogenesis was not affected by phentolamine infusion, $4.98 \pm 1.54$ vs. $5.75 \pm 0.52 \%$ (Table II).

Basal lipid oxidation $(0.86 \pm 0.11 \mathrm{mg} / \mathrm{kg} \cdot \mathrm{min})$ declined by $68 \%$ to $0.33 \pm 0.08 \mathrm{mg} / \mathrm{kg} \cdot \mathrm{min}$ during the control insulin clamp study. When propranolol was infused with insulin the decline in lipid oxidation was slightly but significantly less $(0.50 \pm 0.07$ $\mathrm{mg} / \mathrm{kg} \cdot \min , P<0.02$ ). Protein oxidation during the insulin clamp was similar with $(0.65 \pm 0.04 \mathrm{mg} / \mathrm{kg} \cdot \mathrm{min})$ and without $(0.66 \pm 0.05 \mathrm{mg} / \mathrm{kg} \cdot \mathrm{min})$ propranolol. Basal lipid oxidation $(0.75 \pm 0.20 \mathrm{mg} / \mathrm{kg} \cdot \mathrm{min})$ was unaffected by phentolamine $(0.74 \pm 0.15 \mathrm{mg} / \mathrm{kg} \cdot \mathrm{min})$. The decline in lipid oxidation was similar during the insulin clamp studies performed with $(0.42 \pm 0.19 \mathrm{mg} / \mathrm{kg} \cdot \mathrm{min})$ and without $(0.42 \pm 0.16 \mathrm{mg} / \mathrm{kg} \cdot \mathrm{min})$ phentolamine. Protein oxidation during the control and phentolamine insulin clamp studies was similar $(0.53 \pm 0.06$ vs. $0.54 \pm 0.07 \mathrm{mg} / \mathrm{kg} \cdot \mathrm{min}$, respectively).

Plasma catecholamine concentrations. Basal plasma norepinephrine, $216 \pm 12 \mathrm{pg} / \mathrm{ml}$, and epinephrine, $38 \pm 5 \mathrm{pg} / \mathrm{ml}$, did not change significantly during the 2 -h euglycemic insulin clamp study (Table III). When propranolol was infused alone for $1 \mathrm{~h}$ before starting the insulin clamp neither plasma epinephrine nor norepinephrine levels changed. During the insulin clamp study performed with propranolol there was a small increase in plasma epinephrine ( $56 \pm 5$ vs. $38 \pm 7, P<0.05$ ); plasma norepinephrine remained unchanged.

\section{Discussion}

After the ingestion or infusion of glucose there is an increase in energy expenditure that has been estimated to represent 5 $10 \%$ of the energy content of the administered glucose load (113). Under the present experimental conditions of euglycemic hyperinsulinemia $(\sim 100 \mu \mathrm{U} / \mathrm{ml})$, the increment in energy expenditure above postabsorptive values averaged $0.10 \pm 0.01 \mathrm{kcal} /$ min, from which it can be calculated that glucose/insulin-induced thermogenesis was $4.9 \pm 0.5 \%$. This agrees well with previously published results in which glucose/insulin-induced thermogenesis was found to range from 5 to $10 \%(1,3,4,7,8,10-13)$. Of particular note in the present study was the ability of propranolol, a nonselective beta adrenergic blocking agent, to inhibit the rise in energy expenditure $(0.03 \pm 0.01 \mathrm{kcal} / \mathrm{min}, P<0.001)$ and glucose/insulin-induced thermogenesis $(1.5 \pm 0.5 \%, P<0.001)$. Since infusion of propranolol for $3 \mathrm{~h}$ had no discernible effect on basal energy expenditure, it can be assumed that its inhibitory effect on thermogenesis is linked to some aspect of insulinstimulated cellular metabolism.

It is well known that both insulin and glucose administration will lead to an increase in muscle and liver glycogen content (44-49). When glucose is converted directly to glycogen, a finite amount of energy must be expended (17). If one makes the assumption that all of the glucose that is not oxidized is converted to glycogen, one can calculate the theoretical energy cost of this process by multiplying the rate (milligrams per minute) of "glucose storage" (i.e., nonoxidative glucose uptake) by the value for the energy cost of glucose storage as glycogen $(0.20 \mathrm{kcal} / \mathrm{g})$.

Table III. Summary of Catecholamine Data during the Control Insulin Clamp and Propranolol/Insulin Clamp Studies.

\begin{tabular}{lll}
\hline & Norepinephrine & Epinephrine \\
\hline & $p g / m l$ & $p g / m l$ \\
Control insulin clamp & & \\
$\quad$ Basal & $216 \pm 42$ & $38 \pm 5$ \\
Insulin & $246 \pm 28$ & $43 \pm 5$ \\
Propranolol/insulin clamp & & \\
$\quad$ Basal & $210 \pm 18$ & $38 \pm 7$ \\
Propranolol Alone & $224 \pm 22$ & $42 \pm 7$ \\
Propranolol + Insulin & $241 \pm 21$ & $56 \pm 5^{*}$ \\
\hline
\end{tabular}

$* P<0.05$. 
This latter value can be estimated by multiplying the energy released during the complete combustion of $1 \mathrm{~g}$ of glucose $(3.75$ $\mathrm{kcal} / \mathrm{g}$ ) by $5.3 \%$. The $5.3 \%$ figure is derived from the ratio of the number $(n=2)$ of ATP moles consumed in glycogen synthesis to the number $(n=38)$ of ATP moles produced during the complete combustion of one mole of glucose (17). Using this line of reasoning, it can be calculated that the increase in energy expenditure would be $0.06 \pm 0.01 \mathrm{kcal} / \mathrm{min}$ or $60 \%$ of the actually measured increase $(0.10 \pm 0.01 \mathrm{kcal} / \mathrm{min})$ in energy expenditure. This value agrees well with previously published results (54\%) from our laboratory (13). However, recent evidence would suggest that a significant fraction of glycogen formation is derived from glucose that has been recycled through three carbon compounds, primarily lactate $(45,50-52)$. This process consumes more energy than direct conversion of glucose to glycogen, since $4 \mathrm{~mol}$ of high energy phosphate are consumed for each mole of glucose. Although a quantitative estimate of the amount of glycogen formed directly from glucose vs. that from recycling via lactate is not presently available, this latter process appears to produce a considerable amount of glycogen (53). Thus, it is likely that as much as $70-80 \%$ of the increment in energy expenditure can be accounted for by the eventual conversion of glucose to glycogen.

When propranolol was infused during the insulin clamp study, the increase in energy expenditure was diminished by $70 \%(0.10 \mathrm{vs} .0 .03 \mathrm{kcal} / \mathrm{min})$ without any change in nonoxidative glucose uptake. These results indicate that the inhibition of thermogenesis by beta adrenergic blockade cannot be explained by a decrease in nonoxidative glucose utilization per se. However, it is possible that propranolol administration caused a decrease in glucose recycling via lactate and an absolute proportional increase in glucose conversion directly to glycogen. This would not alter the total amount of glucose disposed of by nonoxidative pathways. It would, however, lead to a decrease in energy expenditure since only $2 \mathrm{~mol}$ of ATP (as opposed to $4 \mathrm{~mol}$ ) would be consumed per mole of glucose converted to glycogen. Since catecholamines are known to stimulate Cori cycle activity (54), it is tempting to speculate that beta adrenergic blocking agents might have the opposite effect. If so, it is at least plausible that part of the decrease in energy expenditure observed with propranolol could be due to a decrease in insulin-stimulated glucose recycling.

During the insulin clamp some of the infused glucose must be converted to lipid (55). This process is associated with a high energy cost (24\% of the glucose energy content as opposed to $5.3 \%$ for glucose conversion to glycogen) (17). If propranolol were to decrease the conversion of glucose to lipid and proportionately augment the flux of glucose to glycogen, the increase in energy expenditure also would be blunted without any change in total nonoxidative glucose uptake. From a purely quantitative standpoint, however, such an explanation is unlikely to account for the decrease in energy expenditure since Bjorntorp et al. $(55-57)$ have estimated that $<1 \%$ of an intravenously administered glucose load is converted to lipid.

It is known that exogenous infusion of both norepinephrine
(30) and epinephrine (31) will cause an increase in oxygen consumption and energy expenditure. Following carbohydrate feeding there is an increase in sympathetic nervous system activity as manifested by an enhanced rate of norepinephrine turnover (1, 22-29). Recently Rowe et al. (23), using the euglycemic insulin clamp technique, have demonstrated a doubling of plasma norepinephrine levels when the plasma insulin concentration is raised by $100-200 \mu \mathrm{U} / \mathrm{ml}$. In the present study, neither plasma epinephrine nor norepinephrine levels increased significantly. This does not, however, exclude the possibility that the sympathetic nervous system was stimulated. In fact, our observations would suggest that a significant portion of the increase in energy expenditure that accompanies glucose/insulin infusion may indeed be related to enhanced sympathetic nervous system activity.

The remaining thermogenesis due to glucose/insulin infusion with propranolol $(0.03 \mathrm{kcal} / \mathrm{min})$ amounts to $2.7 \%$ of energy content of glucose infused. This is less than the cost of glycogen synthesis (i.e., 5.3\%). It is to be acknowledged, however, that the variability of the indirect calorimetry is in the range of $\pm 0.02-0.03 \mathrm{kcal} / \mathrm{min}$. Thus, the absolute value of the remaining thermogenesis is uncertain. In spite of this, it is clear that propranolol induces a significant inhibition of the glucose/insulininduced thermogenesis. In a recent study in which propranolol was given after $2 \mathrm{~h}$ of sustained hyperglycemic hyperinsulinemia (hyperglycemic clamp technique), glucose-induced thermogenesis was inhibited by $30 \%$ (58). This inhibition was significantly less than that observed in the present study and may be due to several factors, including different experimental conditions, more effective beta blockade in our study, or the blunted increase in plasma norepinephrine levels under hyperglycemic conditions (23).

It should be remembered that both epinephrine and norepinephrine possess beta (as well as alpha) adrenergic activity. The ability of propranolol to inhibit the increment in energy expenditure after glucose/insulin infusion indicates that the beta adrenergic receptor, in large part, mediates this response. In this regard our results are consistent with recent studies in animals that have demonstrated that thermogenesis is stimulated by beta adrenergic agonists and blocked by beta antagonists $(59,60)$. In contrast alpha adrenergic agonists and antagonists have no effect on thermogenesis by brown adipose tissue (59).

In the present study we also examined the role of the alpha adrenergic nervous system in glucose/insulin-induced thermogenesis by repeating the insulin clamp studies in combination with phentolamine in five subjects. Under conditions of euglycemic hyperinsulinemia, phentolamine had no effect on total glucose uptake, glucose oxidation, or nonoxidative glucose disposal (Table I). During the first hour after phentolamine infusion there was a small, but statistically insignificant increase in energy expenditure. During the $60-120-\mathrm{min}$ period of the insulin clamp/ phentolamine study, energy expenditure increased to $1.17 \mathrm{kcal} /$ $\min$. Whether the increment in energy expenditure above base line is calculated from the prephentolamine period $(0.18 \mathrm{kcal} /$ $\mathrm{min})$ or from the phentolamine period $(0.12 \mathrm{kcal} / \mathrm{min})$, it is 
clear that alpha adrenergic blockade did not inhibit the thermogenic response to glucose/insulin infusion (Table II).

In summary, the present results demonstrate that combined glucose/insulin infusion enhances oxygen consumption and energy expenditure in healthy subjects. This thermogenic response is largely blocked with the beta adrenergic antagonist propranolol and is unaffected by the alpha adrenergic antagonist phentolamine. These results are consistent with animal studies $(59,60)$ and suggest that the thermogenic response to glucose/insulin is mediated, in part, via the beta adrenergic receptor.

\section{Acknowledgments}

The authors would like to thank Dr. Rosa Hendler for performing the insulin determinations, Louise Derbacher for her excellent secretarial assistance, and the nursing staff of the Clinical Research Center.

This work was supported in part by National Institutes of Health Research grants AM-24092 and RR-125.

\section{References}

1. Welle, S., U. Lilavivat, and R. G. Campbell. 1981. Thermic effect of feeding in man: increased plasma norepinephrine levels following glucose but not protein or fat consumption. Metab. Clin. Exp. 30:953958.

2. Deuel, H. J., Jr. 1927. Specific dynamic action and effects of diet. J. Biol. Chem. 75:367-381.

3. Garrow, J. S. 1971. Specific dynamic action. In Energy Balance in Man. Masson, Paris. 209-218.

4. Garrow, J. S., and S. F. Hawes. 1972. The role of amino acid oxidation in causing specific dynamic action in man. Br. J. Nutr. 27:211219.

5. Garrow, J. S. 1978. In Energy Balance and Obesity in Man. Second Ed. Elsevier/North Holland, Amsterdam. 95-98.

6. Glickman, N., H. H. Mitchell, E. H. Lambert, and R. W. Keeton. 1948. Total specific dynamic action of high protein and high carbohydrate diets on human subjects. J. Nutr. 36:41-57.

7. Pittet, P., P. H. Gigax, and E. Jequier. 1974. Thermic effect of glucose and amino acids in man studied by direct and indirect calorimetry. Br. J. Nutr. 31:343-349.

8. Pittet, P., P. Chappuis, K. Acheson, F. de Techtermann, and E. Jequier. 1976. Thermic effect of glucose in obese subjects studied by direct and indirect calorimetry. Br. J. Nutr. 35:281-292.

9. Swift, R. W., G. P. Barron, K. H. Fischer. C. E. French, E. W. Hartsook, T. V. Hershberger, E. Keck, T. A. Long, and N. D. Magruder. 1958. The effect of high versus low protein equicaloric diets on the heat production of human subjects. J. Nutr. 65:89-102.

10. Swindells, Y. E. 1972. The influence of activity and size of meals on caloric response in women. Br. J. Nutr. 27:65-73.

11. Zwillich, C., B. Martin, F. Hofeldt, A. Charles, V. Subryan, and K. Burman. 1981. Lack of effects of beta sympathetic blockade on the metabolic and respiratory responses to carbohydrate feeding. Metab. Clin. Exp. 30:451-456.

12. Thiebaud, D., E. Jacot, R. A. DeFronzo, E. Maeder, E. Jequier, and J. P. Felber. 1982. The effect of graded doses of insulin on total glucose uptake, glucose oxidation, and glucose storage. Diabetes. 31:957963.

13. Thiebaud, D., Y. Schutz, K. Acheson, E. Jacot, R. A. DeFronzo,
J. P. Felber, and E. Jequier. 1983. Energy cost of glucose storage in man during glucose/insulin infusions. Am. J. Physiol. 244:E216-E221.

14. Rothwell, N. J., and M. J. Stock. 1981. A role for insulin in the diet-induced thermogenesis of cafeteria-fed rats. Metab. Clin. Exp. 30:673-678.

15. Perkins, M. N., N. J. Rothwell, M. J. Stock, and T. W. Stone. 1981. Activation of brown adipose tissue thermogenesis by the ventromedial hypothalamus. Nature (Lond.). 289:401-402.

16. Rothwell, N. J., M. J. Stock, and R. S. Tyzbir. 1983. Mechanisms of thermogenesis induced by low protein diets. Metab. Clin. Exp. 32:257261.

17. Flatt, J. P. 1978. The biochemistry of energy expenditure. In Recent Advances in Obesity Research. II. Newman Publishing, London. 211-228.

18. Ball, E. G. 1965. Some energy relationships in adipose tissue. Ann. NY Acad. Sci. 131:225-234.

19. Ball, E. G., and R. L. Jungas. 1964. Some effects of hormones on the metabolism of adipose tissue. Recent Prog. Horm. Res. 20:183214.

20. Stirling, J. L., and M. J. Stock. 1971. Non conservative mechanisms of energy metabolism in thermogenesis. In Energy Balance in Man. Masson, Paris. 219-228.

21. Clausen, T., and P. G. Kohn. 1977. The effect of insulin on the transport of sodium and potassium in rat soleus muscle. J. Physiol. 265:19-42.

22. Landsberg, L., and J. B. Young. 1981. The sympathetic nervous system and carbohydrate metabolism. In Recent Advances in Obesity Research. III. John Libbey, London. 42-51.

23. Rowe, J. W., J. B. Young, K. L. Minaker, A. L. Stevens, J. Pallotta, and L. Landsberg. 1981. Effect of insulin and glucose infusions on sympathetic nervous system activity in normal man. Diabetes. 30:219225.

24. Schwartz, R. S., J. B. Halter, and E. L. Bierman. 1983. Reduced thermic effect of feeding in obesity: role of norepinephrine. Metab. Clin. Exp. 32:114-117.

25. Welle, S. L., and R. C. Campbell. 1983. Normal thermic effect of glucose in obese women. Am. J. Clin. Nutr. 37:87-92.

26. Young, J. B., and L. Landsberg. 1979. Effect of diet and cold exposure on norepinephrine turnover in pancreas and liver. Am. J. Physiol. 236:E524-E533.

27. Young, J. B., and L. Landsberg. 1977. Stimulation of the sympathetic nervous system during sucrose feeding. Nature (Lond.). 269:615617.

28. Young, J. B., J. W. Rowe, and J. A. Pallotta. 1980. Enhanced plasma norepinephrine response to upright posture and oral glucose administration in elderly human subjects. Metab. Clin. Exp. 29:532539.

29. Landsberg, L., and J. B. Young. 1978. Fasting, feeding, and regulation of the sympathetic nervous system. $N$. Engl. J. Med. 298:12951301.

30. Jung, R. T., P. S. Shetty, and W. P. T. James. 1979. Reduced thermogenesis in obesity. Nature (Lond.). 279:322-323.

31. Muller-Hess, R., C. A. Geser, P. Pittet, P. Chappuis, E. Jequier, and J. P. Felber. 1975. Interactions of insulin and epinephrine in human metabolism: their influence on carbohydrate and lipid oxidation rate. Diabete Metab. 1:151-157.

32. McGuire, E. A. M., J. H. Helderman, J. D. Tobin, R. Andres, and M. Berman. 1976. Effects of arterial versus venous samples. An analysis of glucose kinetics in man. J. Appl. Physiol. 41:565-73.

33. DeFronzo, R. A., J. D. Tobin, and R. Andres. 1979. Glucose 
clamp technique: a method for quantifying insulin secretion and resistance. Am. J. Physiol. 237:E214-23.

34. Dubois, E. F. 1924. Basal Metabolism in Health and Disease. Lea and Febiger, Philadelphia. 23.

35. Lusk, G. 1924. Animal calorimetry: analysis of the oxidation of mixtures of carbohydrate and fat. J. Biol. Chem. 59:41-42.

36. Bursztein, S., P. Saphar, P. Glaser, U. Taitelmann, S. de Myttenaere, and R. Nedey. 1977. Determination of energy metabolism from respiratory functions alone. J. Appl. Physiol. 42:117-119.

37. Jequier, E. 1981. Long term measurement of energy expenditure in man: direct or indirect calorimetry? In Recent Advances in Obesity Research. P. Bjorntorp, M. Castella, and A. N. Howard, editors. John Libbey, London. 3:130-35.

38. Rosselin, G. R. S., R. S. Assan, R. Yalow, and S. A. Berson. 1966. Separation of antibody-bound and unbound peptide hormones labelled with iodine ${ }^{131}$ by talcum powder and precipitated silica. Nature (Lond.). 194:495-496.

39. Hawk, P. B. 1947. Practical physiological chemistry. In Kjeldahl Method, 12th ed. Blakiston, Toronto. 814-22.

40. Cryer, P. E. 1976. Isotope-derivative measurement of plasma norepinephrine and epinephrine in man. Diabetes. 25:1071-1085.

41. DeFronzo, R. A., E. Ferrannini, R. Hendler, P. Felig, and J. Wahren. 1983. Regulation of splanchnic and peripheral glucose uptake by insulin and hyperglycemia in man. Diabetes. 32:35-45.

42. Deibert, D. C., and R. A. DeFronzo. 1980. Epinephrine-induced insulin resistance in man. $J$. Clin. Invest. 65:717-721.

43. Thiebaud, D., K. Acheson, Y. Schutz, J. P. Felber, A. Golay, R. A. DeFronzo, and E. Jequier. 1983. Stimulation of thermogenesis in man following combined glucose-long chain triglyceride infusion. Am. J. Clin. Nutr. 37:603-611.

44. Hess, H. C. 1976. The control of glycogen metabolism in the liver. Annu. Rev. Biochem. 45:167-89.

45. Nilsson, L., and E. Hultman. 1974. Liver and muscle glycogen in man after glucose and fructose infusion. Scand. J. Clin. Lab. Invest. 33:5-10.

46. Chiasson, J., M. R. Dietz, M. Shikama, M. Wotten, and J. H. Exton. 1980. Insulin regulation of skeletal muscle glycogen metabolism. Am. J. Physiol. 239:E69-E74.

47. Roch-Nordlund, A. E., J. Bergstrom, and E. Hultman. 1972. Muscle glycogen and glycogen synthetase in normal subjects and in patients with diabetes mellitus. Effects of intravenous glucose and insulin administration. Scand. J. Clin. Lab. Invest. 30:77-84.

48. Bergstrom, J., and E. Hultman. 1967. Synthesis of muscle glycogen in man after glucose and fructose infusion. Acta Med. Scand. 182:93107.

49. Hultman, E., and J. Bergstrom. 1967. Muscle glycogen synthesis in relation to diet studied in normal subjects. Acta Med. Scand. 182:10917.

50. Jeffcoate, S. L., and A. J. Moody. 1969. The role of the liver in the disposal of orally administered ${ }^{14} \mathrm{C}$-glucose in the normal rat. Diabetologia. 5:293-299.

51. Shikama, H., and M. Ui. 1978. Glucose load diverts hepatic gluconeogenic product from glucose to glycogen in vivo. Am. J. Physiol. 235:E354-360.

52. Baek, A., and J. Radziuk. 1980. Sources of hepatic glycogen formation in conscious fasted rats during intraduodenal glucose loading. Clin. Res. 28:385A. (Abstr.)

53. Radziuk, J. 1982. Sources of carbon in hepatic glycogen synthesis during absorption of an oral glucose load in humans. Fed. Proc. 41:110116.

54. Kusaka, M., and M. Ui. 1977. Activation of the Cori cycle by epinephrine. Am. J. Physiol. 232:E145-E155.

55. Björntorp, P., and L. Sjöstrom. 1978. Carbohydrate storage in man. Speculations of some quantitative considerations. Metab. Clin. Exp. 27 (Suppl. 2):1853-1963.

56. Björntorp, P., M. Krotkiewski, B. Larsson, and A. Somlo-Szucs. 1970. Effects of feeding states on lipid radioactivity in liver, muscle and adipose tissue after injection of labelled glucose in the rat. Acta Physiol. Scand. 80:29-38.

57. Björntorp, P., P. Berchtold, and B. Larsson. 1971. The glucose uptake of human adipose tissue in obesity. Eur. J. Clin. Invest. 1:48085.

58. Acheson, K., E. Jequier, and J. Wahren. 1983. Influence of $\beta$ adrenergic blockade on glucose-induced thermogenesis in man. J. Clin. Invest. 72:981-986.

59. Perkins, M. N., N. J. Rothwell, M. J. Stock, and T. W. Stone. 1981. Activation of brown adipose thermogenesis by the ventromedial hypothalamus. Nature (Lond.). 289:401-402.

60. Rothwell, N. J., and M. J. Stock. 1979. A role for brown adipose tissue in diet-induced thermogenesis. Nature (Lond.). 281:31-35. 